\title{
STUDIES IN CHEMISTRY OF SOME PYRAZOLINES AND ITS BIOLOGICAL SCREENING.
}

\author{
Reshal Deshmukh \\ Shivaji Science College, Congress Nagar, Nagpur:440012,(MS) India \\ E.mail- reshaldeshmukh@rediffmail.com
}

\begin{abstract}
:
Biologically active Pyrazoline derivatives were efficiently synthesized in excellent yields and in less reaction time using ethanol via cyclization reaction of chalcones and Substituted hydrazines. These newly synthesized compounds were screened for their antimicrobial potencies which reflects moderate to good activity against different strains of bacteria and fungi employed. All the synthesized compounds were confirmed by IR, 1HNMR and Mass spectral data.
\end{abstract}

Key words: - Chalcones, Substituted Hydrazine, Pyrazolines, Antimicrobial activities

\section{INTRODUCTION:}

Due to the rapid development of bacterial resistance to antibacterial agents, it is vital to discover novel scaffold for the design and synthesis of the new antibacterial agents to help in the battle against pathogenic microorganisms. Chalcones represent an essential group of natural as well as synthetic products and some of them possess wide range of pharmacological activity such as antibacterial $^{1}$, antitumour ${ }^{2}$, anticancer ${ }^{3}$, antitubercular $^{\mathbf{4}}$, antiinflammatory, ${ }^{\mathbf{5}}$ antioxidant $\mathbf{6}^{\mathbf{6}}$, antimalarial $^{\mathbf{7}}$, antileishmanial $\mathbf{8}^{\mathbf{3}}$ etc. The presence of reactive $a, \beta$-unsaturated keto group in chalcones is found to be responsible for their biological activity. In the present work chalcones have been prepared according to claisen-schimidt condensation by condensing various ketones with aromatic aldehyde. Available data suggest that $\mathrm{N}$ containing heterocyclic compounds from chalcones possesses wide variety of activities9-12 such as potential cytotoxic agents, antimicrobial agents, antiviral, antiinflammatory, anesthetics, mydriatics etc. Led by these considerations, it appeared of interest to synthesize novel pyrazoline derivatives and screened for their antimicrobial activitie

\section{MATERIAL AND METHODS :-}

Section $-A$

Preparation of Acetophenone:
The 2-Hydroxy-5-chloroacetophenone (IIa) was prepared by Fries migration of p-chlorophenol acetate (Ia) in presence of $\mathrm{AlCl}_{3}, \mathrm{mp} .55^{\circ} \mathrm{C}$

Preparation of 2-Hydroxy- 3-bromo-5chloroacetophenone (IIb):

The 2-Hydroxy- 3-bromo-5-chloroacetophenone (IIb) was prepared by the bromination of acetophenone (IIa) with bromine in acetic acid $\mathrm{mp}$. $90^{\circ} \mathrm{C}$.

\section{Section -B}

Preparation ofChalcones:

Acetophenone (IIa-b) on condensation with aldehydes gave corresponding chalcones. The following chalcones were prepared.

Condensation with Anisaldehyde:

2-Hydroxy- 3-bromo-5-chloro-4-anisylchalcone (IIIa) mp. $172^{\circ} \mathrm{C}$

Condensation with Benzaldehyde:

2-Hydroxy- 3-bromo-5-chloro chalcone (IIIb). mp 1240

\section{Section C}

1.Preparation of 1-Phenyl-3-(2-hydroxy-3-bromo5-chlorophenyl)-5-anisyl-2-Pyrazoline(IVa)

A mixture of 2-Hydroxy- 3-bromo-5-chloro-4anisyl chalcone (IIIa) (0.01mole) and 99\% Phenyl hydrazine (IIa) $(0.015 \mathrm{~mole}, 0.6 \mathrm{ml})$ in ethanol $(60 \mathrm{ml})$ was refluxed for about two hours. The reaction mixture was then concentrated and allowed to cool.The resulting solid was filtered,washed with ethanol and crystallized from ethanol to get yellow solid of 
1-Phenyl-3-(2-hydroxy-3-bromo-5-chlorophenyl)5-anisyl-2-Pyrazoline(IVa) mp.142 ${ }^{\circ} \mathrm{C}$,Yield $75 \%$

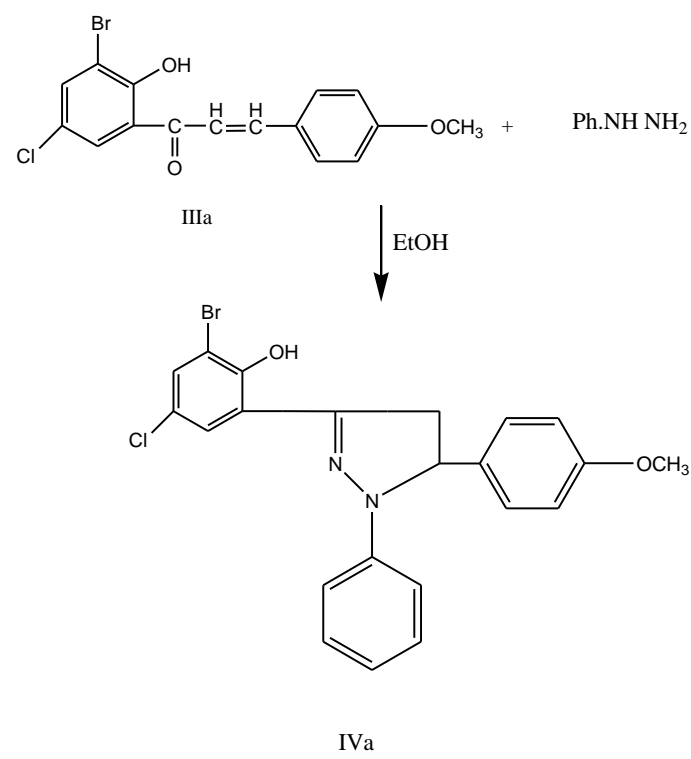

2.Preparation of 1-(2,4dinitro phenyl)-3- (2hydroxy -3 -bromo- 5- chlorophenyl) -5-phenyl 2- Pyrazoline (IVb)

A mixture of 2-Hydroxy- 3-bromo-5-chlorochalcone (IIIb) (0.01mole, 3.37g) and 99\% 2,4-dinitro phenyl hydrazine (IIa) $(0.015 \mathrm{~mole}, 0.6$ $\mathrm{ml})$ in ethanol $(60 \mathrm{ml})$ was refluxed for about two hours. The reaction mixture was then concentrated and allowed to cool. The resulting solid was filtered, washed with ethanol and crystallized from ethanol to get yellow solid of 1-(2,4dinitro phenyl)-3-(2-hydroxy-3-bromo-5-chlorophenyl)-5phenyl-2-Pyrazoline(IVb) mp. $175^{\circ} \mathrm{C}$, Yield $75 \%$<smiles>CC(O)CCCCONC(=O)NN</smiles><smiles>O=[N+]([O-])c1ccc(N2N=C(c3cc(Cl)cc(Br)c3O)CC2c2ccccc2)c([N+](=O)[O-])c1</smiles>

RESULT AND DISCUSSION:
1.Preparation of 1-phenyl-3-(2-hydroxy-3-bromo5-chlorophenyl)-5-anisyl-2-Pyrazoline(IVa)

2-Hydroxy- 3-bromo-5-chloro-4-methoxy chalcone (III) and hydrazine hydrate in ethanol on refluxing gave yellow solid(IVa) $\mathrm{mp} 124^{\circ} \mathrm{C}$ Yield$70 \%$

The compound (IVa) is yellow coloured crystalline solid mp $124 \mathrm{C}^{0}$

2.It gives green colouration with neutral $\mathrm{FeCl}_{3}$ solution.indicating presence of free phenolic $-\mathrm{OH}$ group.

3.It gives deep blue colouration with $\mathrm{concH}_{2} \mathrm{SO}_{4}$ solution showing the absence of $-\mathrm{C}-\mathrm{CH}=\mathrm{CH}-$ linkage

4.Purity of the compound was tested by TLC

5. From analytical data molecular formula of the compound (IVa) was found to be $\mathrm{C}_{22} \mathrm{H}_{19} \mathrm{O}_{2} \mathrm{~N}_{2} \mathrm{BrCl}$ 6 The I.R and NMR spectra of the compound (IVa)

\section{Antimicrobial Activity of Synthesised Compounds}

The pyrazoline when screened in vitro against the test organisms Salmonella typhi , Salmonella paratyphi , Proteus vulgaris , Xanthomonas ,Fusarium solanii and Botrytis cinerea. and it was noticed that most of all these compounds have shown remarkable inhibitory activity. An assay of newly synthesized Chalcones, pyrazolines and Acety Pyrazolines revels that, almost all the compounds were strongly active against all the test pathogens. The minimum inhibitory concentration (MIC) values were determined by serial dilution method. The comparative study of MIC values of the compound are given in the Tables 1 and 2

\section{REFERENCES:-}

Hogale M.B., Dhore N.P., Shelar A.R. andPawar P.K., Synthesis and biological activity of some urethane derivatives of chalcones, OrientJ. Chem., 1986, 2, 55.

Yamakawa T., Kagechika H., Kawachi E.,Hashimoto Y. and Shedo K., Retinobenzoicacids -5Retinoidal activities of compoundshaving a trimethylsilyl or trim-ethylgermylgroup(s) in human promyelocytic leukemia cellsHL-60, J. Med. Chem., 1990, 33, 1430.

Ahluwalia V.K., Nayal L., Kalia N., Bala S. andTahim, A.K., Synthesis and antimicrobialactivity of substituted 3,4-dihydro2H-1-benzopyrans, Indian J. Chem., 1987, 26B, 384. 
Bhatt A.K., Bhamaria R.P., Patel M.R., BellareR.A. and Deliwala, C.A., Chemotherapy offungus infections. III. Alkyl or arylthiosemicarbazones, acid hydrazones, and styrylaryl ketones of 5bromo- and 5-nitrosalicylaldehydes, Indian $\mathrm{J}$. Chem., 1972, 10,694.

Mukherjee S., Kumar V., Prasad A.K., Raj H.G.,Brakhe M.E., Olsen C.E., Jain S.C. and ParmarV.S., Synthetic and biological activityevaluation studies on novel 1,3diarylpropenones, Bio-org. Med.Chem., 2001, 9,337.

Indyah S.A., Timmerman H., Samhoedi M.,Sastronami., Sugiyanto and Goot H.V.,Synthesis of benzylideneacetophenones andtheir inhibition of lipid peroxidation, Eur. J.Med. Chem., 2000, 35, 449457.

Chen M., Christensen S., Zhai L., RasmussenM.H., Theander T.G., Frokjaer S., Steffensen B.,Davidson J. and Kharazmi, A., The NovelOxygenated Chalcone, 2,4-Dimethoxy-4'Butoxychalcone, Exhibits Potent Activityagainst Human Malaria Parasite Plasmodiumfalciparum In Vitro and Rodent ParasitesPlasmodium berghei and Plasmodium yoelii InVivo, J.Infect. Dis., 1997, 176(5), 1327-1333.
Nielsen S.F., Christensen S.B., Cruciani G.Kharazmi A., and Liljefors, T., Antileishmanialchalcones: Statistical design, synthesis andthree-dimentional quantitative structure-activityrelationship analysis, J. Med. Chem., 1998, 41,4819-4832.

Vibhute Y.B. and Basser M.A., Synthesis andactivity of a new series of Chalcones asantibacterial agents, Ind.J. of Chem., 2003, 42B,202-205.

Bhat B.A., Dhar K.L., Saxena A.K. andShanmugavel M., Synthesis and biologicalevaluation of Chalcones and their derived Pyrazoles as potential cytotoxic agents, Bio org.\& Med. Chem., 2005, 15(3), 177-3180.

Edwards M.L., Stemerick D.M. and SunkaraP.S., Synthesis of Chalcones: A new class ofAntimitotic agents, J. of Med. Chem., 1990, 33, 1948-54.

Kalirajan R., Palanivelu M., Rajamanickam V.,Vinothapooshan G. and Anandarajagopal K.,Synthesis and biological evaluation of someChalcone derivatives, Int. J. of Chem. Sci.,2007, 5(1), 73-80.

Table-1

\begin{tabular}{|c|l|l|l|l|}
\hline SR.NO & \multicolumn{1}{|c|}{ CHALCONE } & HYDRAZINE & 2-PYRAZOLINE & $\mathrm{Mp}^{0} \mathrm{C}$ \\
\hline 1. & $\begin{array}{l}\text { 2-Hydroxy-3-bromo- } \\
\text { 5-chloro-4- } \\
\text { anisylchalcone (IIIa) }\end{array}$ & $\begin{array}{l}\text { Phenyl } \\
\text { hydrazine }\end{array}$ & $\begin{array}{l}\text { 1-Phenyl-3-(2-hydroxy-3- } \\
\text { bromo-5-chlorophenyl)-5- } \\
\text { anisyl-2-Pyrazoline(IVa) }\end{array}$ & 142 \\
\hline 2 & $\begin{array}{l}\text { 2-Hydroxy-3-bromo-5- } \\
\text { chlorochalcone (IIIb) }\end{array}$ & $\begin{array}{l}\text { 2,4dinitroPhenyl } \\
\text { hydrazine }\end{array}$ & $\begin{array}{l}\text { 1-(2,4 dinitro phenyl)-3-(2- } \\
\text { hydroxy-3-bromo-5- } \\
\text { chlorophenyl)-5-phenyl-2- } \\
\text { Pyrazoline(IVb) }\end{array}$ & 175 \\
\hline
\end{tabular}




\begin{tabular}{|c|c|c|}
\hline Literature value cm-1 & Observsd value & Assignment \\
\hline $3600-3000$ & 3380 & -NH stretching \\
$1700-1550$ & $1540-1550$ & -OH stretching \\
$1300-1100$ & $1240(\mathrm{~s})$ & $-\mathrm{C}-\mathrm{N}$ stretching \\
$1470-1400$ & 1400 & $-\mathrm{CH}_{2}$ stretching \\
$1310-1320$ & 1310 & $-\mathrm{OCH}_{3}$ stretching \\
$800-700$ & 790 & $\mathrm{C}-\mathrm{Cl}$ stretching \\
$700-600$ & 650 & C-Br stretching \\
& & \\
\end{tabular}

The PMR spectrum of the compound (IVa) was recorded as:

\begin{tabular}{|c|c|c|}
\hline Peak observed & Multiplicity & Assignment \\
\hline 3.80 & $\mathrm{~S}$ & $3 \mathrm{H},-\mathrm{OCH}_{3}$ \\
3.06 & $\mathrm{dd}$ & $1 \mathrm{H},-\mathrm{CHH}_{\mathrm{A}}$ \\
3.48 & $\mathrm{dd}$ & $1 \mathrm{H},-\mathrm{CH}_{\mathrm{B}} \mathrm{H}$ \\
4.90 & $\mathrm{dd}$ & $1 \mathrm{H},-\mathrm{CHX}$ \\
$6.8-7.8$ & $\mathrm{~m}$ & $1 \mathrm{H},-\mathrm{NH}$ and $6 \mathrm{H}, \mathrm{Ar}-\mathrm{H}$. \\
11.92 & $\mathrm{~s}$ & $1 \mathrm{H},-\mathrm{OH}$ \\
\hline
\end{tabular}

All these observation confirms the structure of compound(IVa)

Table-3: Minimum Inhibitory Concentration (MIC in \%) of Chalcone

\begin{tabular}{|l|l|l|l|l|l|l|l|}
\hline SR.NO & \multicolumn{1}{|c|}{$\begin{array}{c}\text { Name of the } \\
\text { Compound }\end{array}$} & $\begin{array}{c}\text { S. } \\
\text { typhi }\end{array}$ & $\begin{array}{c}\text { S.para } \\
\text { typhi }\end{array}$ & P.vulgaris & X.sapp & F.solanii & B.cinerea \\
\hline 1 & $\begin{array}{l}\text { 2-Hydroxy- 3-bromo- } \\
\text { 5-chloro-4- } \\
\text { anisylchalcone (IIIa) }\end{array}$ & 0.27 & 0.28 & 0.27 & 0.26 & 0.26 & 0.26 \\
\hline 2 & $\begin{array}{l}\text { 2-Hydroxy- 3-bromo- } \\
\text { 5-chloro chalcone } \\
\text { (IIIb). }\end{array}$ & 0.71 & 0.69 & 0.60 & 0.67 & 0.69 & 0.69 \\
\hline
\end{tabular}

Table-4: Minimum Inhibitory Concentration (MIC in \%) of Pyrazolines

\begin{tabular}{|l|l|l|l|l|l|l|l|}
\hline $\begin{array}{l}\text { SR. } \\
\text { NO }\end{array}$ & Name of the Compound & $\begin{array}{c}\text { S. } \\
\text { typhi }\end{array}$ & $\begin{array}{c}\text { S.para } \\
\text { typhi }\end{array}$ & $\begin{array}{c}\text { P.vulgari } \\
\text { s }\end{array}$ & $\begin{array}{c}\text { X.sap } \\
\mathrm{p}\end{array}$ & $\begin{array}{c}\text { F.sola } \\
\text { nii }\end{array}$ & $\begin{array}{c}\text { B.ciner } \\
\text { ea }\end{array}$ \\
\hline 1 & $\begin{array}{l}\text { 1-phenyl-3-(2-hydroxy- } \\
\text { 3-bromo- } \\
\text { 5chlorophenyl)-5- } \\
\text { anisyl-2-Pyrazoline(IVa) }\end{array}$ & 0.20 & 0.20 & 0.20 & 0.20 & 0.22 & 0.22 \\
\hline 2 & $\begin{array}{l}1-(2,4 \text { dinitro phenyl)- } \\
\text { 3-(2-hydroxy-3-bromo- } \\
\text { 5chlorophenyl)- } \\
\text { 5phenyl-2-Pyrazoline } \\
\text { (IVb) }\end{array}$ & 0.30 & 0.22 & 0.31 & 0.31 & 0.30 & 0.30 \\
\hline
\end{tabular}

